\title{
Brazil and Turkey in the 21st century: strategic interests in comparative perspective
}

1. Esta pesquisa contou com apoio da FAPERGS e do CNPO.

2. Doutor em Ciência Política (UFRGS). Pós-doutorado na School of Oriental and African Studies/University of London. Professor dos PPGs em Ciência Política (PPGCP) e em Estudos Estratégicos Internacionais (PPGEEI) da UFRGS. Porto Alegre, RS, Brasil. Bolsista de Produtividade em Pesquisa do CNPq (P02). Esta pesquisa contou com apoio da FAPERGS e CNPO. ORCID: https://orcid.org/0000-

0003-2593-1189 Email: reisdasilva@ hotmail.com

3. Mestranda pelo Programa Interinstitucional de Pós-Graduação em Relações

Internacionais "San Tiago Dantas" (UNESP, UNICAMP, PUC-SP). Graduada em Relações Internacionais pela UFRGS.

Foi bolsista de mestrado CAPES e bolsista de iniciação científica CNPO.

ORCID: https://orcid.org/0000-0002 1967-1467 Email: gabrielaferreiradacosta@gmail.com

\section{Brasil y Turquía en el siglo XXI: intereses estratégicos en perspectiva comparada}

\section{Brasil e Turquia no século XXI: interesses estratégicos em perspectiva comparada}

\author{
André Luiz Reis da Silva² \\ Gabriela Dorneles Ferreira da Costa ${ }^{3}$
}

DOI: 10.5752/P.2317-773X.2020v8.n4.p132

Received in: August 30, 2020

Accepted in: February 04, 2021

\begin{abstract}
This research aims to compare the strategic interests and the positioning at the foreign policy level of Brazil and Turkey in the 21st century, considering the rise to power of, respectively, Workers' Party (PT, in Portuguese) and Justice and Development's Party (AKP, in Turkish). Methodologically, it was used bibliographical research and analysis of speeches in the General Debate of the United Nations General Assembly (UNGA) between 2010 and 2015. It was verified convergence between Brazil and Turkey in themes as the acknowledgment of the multipolarity of the World Order, the necessity of the United Nations Security Council (UNSC) reform, the importance of the fortification of the global economic governance by G-20 and the compromise with the International Law, with the terrorism combat and with the Humans Right protections. As divergence point, it was verified the debates about the sort of reform to be implemented at the UNSC and some questions involving the Arab Spring, such as the military intervention at Libya in 2011. At last, some themes are more recurrent at one country's foreign policy than another's; as topics regarding Central Asia and Middle East, at Turkey's case, and subjects regarding BRICS and south-american regional integration, at Brazil's case.
\end{abstract}

Keywords: Brazil. Turkey. Foreign Policy. Strategic Interests.

\section{RESUMEN}

Esta investigación tiene como objetivo comparar los intereses estratégicos y el posicionamiento a nivel de política exterior de Brasil y Turquía en el siglo XXI, considerando el ascenso al poder, respectivamente, del Partido de los Trabajadores (PT, en portugués) y el Partido de la Justicia y el Desarrollo (AKP, en turco). Metodológicamente, se utilizó la investigación bibliográfica y análisis de los discursos 
en el Debate General de la Asamblea General de las Naciones Unidas (AGNU) entre 2010 y 2015. Se verificó la ocurrencia de convergencia entre Brasil y Turquía en temas como el reconocimiento de la multipolaridad del Orden Mundial, la necesidad de la reforma del Consejo de Seguridad de las Naciones Unidas (CSNU), la importancia del fortalecimiento de la gobernanza económica global por parte del G-20 y el compromiso con el Derecho Internacional, con el combate al terrorismo y con las protecciones a los Derechos Humanos. Como punto de divergencia, se verificaron los debates sobre el tipo de reforma a implementar en el CSNU y algunas cuestiones relacionadas con la Primavera Árabe, como la intervención militar en Libia en 2011. Por último, se detectaron algunos temas que son más recurrentes en la política exterior de un país que en la de otro; como temas en materia regional de Asia Central y Medio Oriente, en el caso de Turquía, y temas de BRICS e integración regional sudamericana, en el caso de Brasil.

Palabras-clave: Brasil. Turquía. Política Exterior. Intereses Estratégicos.

\section{RESUMO}

Esta pesquisa tem como objetivo comparar os interesses estratégicos e o posicionamento no plano da política externa do Brasil e da Turquia no século 21, considerando a ascensão ao poder de, respectivamente, Partido dos Trabalhadores (PT) e Partido da Justiça e Desenvolvimento (AKP, em turco). Metodologicamente, utilizou-se a pesquisa bibliográfica e a análise de discursos no Debate Geral da Assembleia Geral das Nações Unidas (AGNU) entre 2010 e 2015. Foi verificada a ocorrência de convergência entre o Brasil e a Turquia em temas como o reconhecimento da multipolaridade da Ordem Mundial, a necessidade da reforma do Conselho de Segurança das Nações Unidas (CSNU), a importância do fortalecimento da governança econômica global pelo G-20 e o compromisso com o Direito Internacional, com o combate ao terrorismo e com as proteções dos Direitos Humanos. Como pontos de divergência, verificaram-se os debates sobre o tipo de reforma a ser implementada no CSNU e algumas questões envolvendo a Primavera Árabe, como a intervenção militar na Líbia em 2011. Por fim, foram detectados alguns temas que são mais recorrentes na política externa de um país do que na de outro; como temas relativos a questões regionais da Ásia Central e do Oriente Médio, no caso da Turquia, e assuntos relativos aos BRICS e à integração regional sul-americana, no caso do Brasil.

Palavras-chave: Brasil. Turquia. Política Externa. Interesses Estratégicos.

Introduction

The international transformations occurred with the Cold War's end and with the acceleration of the globalization process accentuated the multipolar tendencies of the international system, opening new possibilities for the international insertion of great peripheral States. Among the diverse concepts and analyses that have been elaborated to comprehend the emergence of intermediate countries, the BRIC concept - created in 2001 by Jim O'Neill, economist of the Goldman Sachs investment bank (O'NEILL, 2001) - was the most popularized, both in the media and in the academic field. In 2003, the BRIC used to correspond to $9 \%$ of the global GDP. Up to 2008, the economies of the four countries already corresponded jointly to $15 \%$ of the global economy, with their GDP adding up to nine trillion of dollars. In 2009, BRIC constituted a political discussion forum, and it embodied South Africa in 2011 (becoming "BRICS"). 
On the other hand, lots of works point other intermediate, medium or emerging powers as holders of significant capacities, mostly smaller than those of BRICS', but that can also influence regionally and, especially, affect the condition of regional power of BRICS countries (NOLTE, 2010). The emerging countries represent, increasingly, an object of interest for Brazilian foreign policy, as they constitute regional references of development, are intermediate States in terms of power and influence in the international system, and can support the Brazilian aspirations for medium power status. However, many have historical ties (economic and military) with developed countries. In this context, there is Turkey, holder of strategic importance in the Middle East and considered regional and intermediate power. This way, this research aims to identify the limits and the possibilities of international action of intermediate powers as Brazil and Turkey.

The following study has been developed in a context of frequents questionings about the similarities of the Brazilian and the Turkish behaviors at the international arena since the rise to power of the Worker's Party (PT, in Portuguese) and the Justice and Development Party (AKP, in Turkish). In that sense, the main objective of this research is to identify points of convergence and divergence in the international agenda of those countries, considering their respective political and social bases for the foreign policy formulation and their central axes of international integration.

Therefore, the core question to be answered is whether the position of these countries as emerging powers in the international system gives them convergent positioning, identifying if Turkey has been building routes of convergence with Brazil's foreign policy. To answer to this matter, the comparative method - a systemic procedure of case analysis - can be used, comparing the countries and establishing their similarities and differences, thus being "extremely useful to create and test propositions about the foreign policy behavior that apply to two or more cases" (ROSENAU, 1968, p. 308).

Foreign policy comparative analysis, based on a limited number of cases, has as methodology, basically, the identification and description of the core variables involved at the problem (LIJPHART, 1971). Here, the main independent variable is the fact that both countries are considered emerging. The international themes selected, identified as Brazilian strategic interests, act as dependent variables, which allow the observation of the similarities and differences in the foreign policies of these countries. The main intervenient variables are the relative capabilities (economic and military), their relative positions in their regions, their development models, their relations with the United States of America (USA), and their position regarding the debate on multipolarity. However, this research recognizes the difficulty of clearly separating the variables' orders, given the complexity of this analysis, generating overdetermination of variables, which can reinforce or exclude each other (HUDSON; VORE, 1995).

Thereby, seeking torender the comparison operational, the following variables have been chosen: a) economic development model; b) relations with the USA; c) defense of multipolarity; d) United Nations Security Council (UNSC)'s reform; e) climate change and development; f) terrorism and Humans Rights; g) nuclear research development; h) World 
Trade Organization (WTO) - trade liberalization and the Doha Round; i) global economic governance (G-20); j) South-South cooperation; k) regional integration. The position of both countries regarding the events of the Arab Spring was also compared. Concerning the research techniques, the authors have used bibliographical research of both primary and secondary sources. So, the present work was built through the investigation of books and articles and through speech' analysis of the Brazilian and Turkish representatives' participation at the General Debate of the United Nations General Assembly (UNGA) between 2010 and 2015.

Changes to Brazilian foreign policy

The revision of Brazil's matrix of international integration, which was in force in the 1990s, implied a redefinition of multilateral, regional and bilateral priorities. Brazil seeks a broad multilateral and universalist agenda, advocating mainly the multipolarity and the democratization of international decision-making bodies, such as the United Nations Security Council. The revaluation of multilateral forums for Brazil to present its points of view, win supporters and articulate channels of collective interests represents a new form of international integration, distinct from the previous matrix. A change in the scope of multilateral relations can be identified, with the expansion of strategic partnerships and coalition groups, seeking to advance diplomatically regarding the previous decade (AMORIM, 2004).

With the change of government in 2003, when Luiz Inácio Lula da Silva took over the presidency, multilateral policy remained central, but its content and strategies were reoriented. The new multilateral conception is based on a new reading of the international system, which identifies its power diffusion and multipolar tendencies, but recognizes its institutional constraint that hinders the insertion of developing countries. So, it defends the need for greater representation in discussion forums in order to democratize and increase the efficiency of organizations such as the United Nations. Regarding action, it seeks to explore new spaces of bargaining and negotiation, through intense use of articulation groups. According to Maria Regina Soares de Lima (2005), the Lula government's emphasis on multilateralism would be interrelated with the perception of Brazil's position in the international scenario as a medium power, "which sees in the mediation between the strong and weak its main contribution to the international stability and the recognition of its international projection not by force, but by parliamentary diplomacy" (LIMA, 2005, p. 15).

On the other hand, the multilateral agenda has gained new perspective, associating substantial issues of economic development and trade liberalization to the need for greater democratization of the decision-making process (mainly in the UN). It develops institutionalized coordination with developing countries, in forums such as IBSA and G-20. Thus, the Lula government accentuates the action on the horizontal-multilateral axis, conceiving an autonomous position for Brazil in the multilateral forums, as a great State, which would seek - by bargaining means rather than by good behavior - to gain greater visibility in the sphere of international power (PECEQUILO, 2008). 
Thereby, in 2003, the country promoted the creation of two blocks, IBSA or G-3 (India, Brazil and South Africa) and the G-20. IBSA represents the institutionalization of the partnership between Brazil, India and South Africa, aiming to promote cooperation on "a wide range of topics ranging from trade to international security” (VIGEVANI; CEPALUNI, 2007, p. 296). The G-20 was established on 20 August 2003 during the preparatory meetings for the $5^{\text {th }}$ WTO Ministerial Conference. The group focuses on agriculture, the central theme of the Doha Development Agenda (OLIVEIRA, 2005). The articulation with the countries known as BRIC (Brazil, Russia, India, and China) was institutionalized in June 2009, in the Russian city of Yekaterinburg, during the $1^{\text {st }}$ BRIC Group Summit.

In that sense, Itamaraty ${ }^{4}$ sought to increase the density of relations in spaces that were previously barely occupied by Brazilian diplomacy in the 1990s, with the approach to South American - especially the Andean - countries, Southern Africa and the Middle East, and to China, India and Russia. In addition, cooperation and deepening of partnerships with these countries allowed the construction of alliances of "variable geometry" such as the G-3, the G-20 and BRIC, in other words, these alliances potentiated Brazil's bilateral relations with countries classified as "strategic partnerships" (CERVO; BUENO, 2011).

By reinforcing its alliances with developing countries, Brazil gradually frees itself from the influence of traditional powers, acquiring greater autonomy. Thus, it is considered that the Brazilian foreign policy in the first decade of the new millennium has constituted a new matrix of international integration, in which it seeks to strengthen regional integration in South America and to recover Brazil's multilateral tradition of critical profile toward international asymmetries, as well as seeks to build strategic partnerships with similar countries in all continents (SILVA, 2015).

However, unlike the developmentalist matrix of the 1970s and 1980s, the new foreign policy matrix is more fluid and multidimensional, with flexible political arrangements, alliances, and strategic partnerships, combining actors, scenarios, and interests. The multidimensionality derives from diplomatic action and articulation in various plans (bilateral, multilateral and regional). It is observed that despite of the intensification of South-South cooperation, the traditional relations were not abandoned. Dilma Rousseff government (2011-2016) embraced this same conception, revealing a continuity regarding the foreign policy developed during the two mandates of President Lula, although some adjustments have been made in the program, mainly, due to the crisis situation that hit global economy and to the domestic political crisis that culminated in the impeachment process in 2016.

Changes to Turkish foreign policy

Turkey is included in a select group of countries that could surpass economically the G-7 countries, except the United States, according to Goldman Sachs forecasts for Next Eleven (N-11). This is due to the structure of the Turkish economy, whose level of maturity and development stands out among the N-11. In fact, Turkey went through several periods 
of economic boom during the twentieth century. At first, the country adopted an import substitution policy, during which it set up its industrial base. Since the 1980s, however, Ankara has abdicated this project in favor of a liberalization strategy to attract foreign investment and boost the manufacturing industry, whose exports have become the engine of production expansion. Thus, Turkey began to integrate the route of international capital flows, boosting its trade balance.

If inclusion in the international market is the main virtue of the Turkish economy, government deficit and technological gap of some of its sectors are the main problems. Despite that, it should be noted that Turkey seems to have made considerable progress in terms of political stability. Throughout the previous century, the country has faced several coups d'état led by the army, which presented itself as the bastion of Turkish secularism. Since 2002, however, a party with Islamic roots that has been committed to institutionalizing democracy and preventing depositions of elected governments has been established. This process crystallizes the transformations of Turkish society, which seem to have already settled the necessary foundations to ensure long-term economic growth. Given its population and its strength in terms of military capabilities, it is presumed that Turkey's influence on the international system will tend to increase considerably in the next decades (WILSON; STUPNYTSKA, 2007, p. 5).

Turkey's international relations are articulated along three main axes, which shape the authorities' responses to the demands of the international system. In the first place, it is essential to connect the country to its geopolitical context, in a position of connection between Europe, Asia and the Middle East. Also important is the question of identity, as there is an important debate regarding the cultural belonging of the Turks, considering the fact that they are embedded in the crossing of different continents. Finally, the problems stemming from Turkish history must be emphasized, since the fact that the country was the seat of a great empire sometimes gives rise to pretensions of greatness in the practice and in the speeches of its leaders. These three factors intertwine and forge Turkish diplomacy (ALTUNISIK; TÜR, 2005).

For example, there are several elements that demonstrate the relevance of these aspects during the Cold War. Geopolitics became very important during the 1980s, due to the Soviet invasion of Afghanistan. The United States assigned much importance to Turkey, which was contemplated with new weapons. In that same period, Turkish aspiration to join the European Community generated many debates in civil society. Members of the Welfare Party (Refah Partisi - RP, in Turkish) even said that this interest was the result of a cruzade project. Subsequently, when the RP came to power, it considered necessary to approach Muslim countries, because the Muslim roots of the country would push it to do so. Other sectors, more linked to secularism, have criticized this position, arguing that Ankara needs to orient itself toward Europe if it wants to progress (ALTUNISIK; TÜR, 2005).

AKP's presence at the heart of the decision-making policies gives a more universal character to Turkish international relations. Although the party carries an inheritance of radical Islam, it has not turned its back on Eu- 
rope; instead, retained the Turkish bid to join the European Union, which is, in fact, a majority's will of the local population. In addition, it has sought to be more active in the rest of the world, as evidenced by the creation of new embassies in Africa and Latin America. The government also encourages new partnerships in the Middle East, considering the region a priority. The rise of the AKP also increases the participation of the popular social classes in issues related to diplomacy, a novelty, as politics in the times of the secularists was, largely, applied from the top to the bottom (HIRO, 2009).

Relations between Turkey and the United States have undergone several oscillations since the end of World War II. During Clinton's administration, the proximity between the two governments remained, which was crystallized in Turkish cooperation in the Balkans, for example. As counterpart, Washington positioned itself in favor of Turkey's accession to the European Community and also favorably to the construction of the Baku-Tbilisi-Ceyhan oil pipeline. At that time, the commercial partnership also increased and, US entrepreneurs started to invest more in the Turkish market, especially in communications, energy and infrastructure (GÜN, 2009).This placidity in relations, however, ended at the Iraq War of 2003, as the Turkish Parliament did not authorize the installation of US troops in Turkish territory, despite the government's interest in doing so. After this event, relations between the two countries entered a phase of uncertainty. Another problem aroused from the Iraq War is the possibility of the emergence of a Kurdish state in the region (ALTUNISIK; TÜR, 2005).

Since Obama's government, few changes have occurred in relation to previous paradigms. The United States continues to argue that the fight against terrorism is one of the pillars of partnership with the Turks, also because Turkey faces this problem domestically due to the PKK (GÜN, 2009). There is also discord over relations with Iran, as Ankara has tried to avoid economic sanctions against Tehran. As a consequence of this position, Obama announced that new arms sales will be subject to Turkish behavior. Obama's criticisms on the Armenian genocide of the early twentieth century also sparked apprehension in the Turkish government, which evidently did not appreciate these comments.

Turkish belonging - or not - to Europe is materialized in the Turkish attempt to join the European Union (EU). Indeed, Ankara demanded entry into the European Economic Community as early as 1959 and obtained associate membership status four years later. In subsequent years, nevertheless, a series of political problems caused the Turkish authorities to avoid an official request to become a full member, being the invasion of Cyprus the main one. European Community countries have severely criticized this attitude, which has made the Turkish government aware of the impossibility of succeeding on this issue. In 1987, then, there was the official attempt, which was rejected two years later. It should also be pointed out that the negative answer was peremptory, without any prospect of reversal (ALTUNISIK; TÜR, 2005).

From the economic point of view, though, this situation changed in the following decade. In 1995, a Customs Union was established between Turkey and the European Union, which determines the free movement of goods between these regions. This rule, however, does not apply to agriculture, 
as some European countries fear the competition from Turkish products (YILMAZ, 2008). In the wake of these events, the government has sought to implement measures aiming to the acceptance of its candidature to the European Union, such as further promotion of Human Rights and suspension of the death penalty. The biggest problem, nevertheless, derives from the fact that the Turkish population exceeds 70 million, raising fears in the European Union about its absorption. The atavistic dispute with the Greeks also does not favor Turkey. It cannot be ignored, either, that the idea of admitting a Muslim nation within Europe displeases many (ALTUNISIK; TÜR, 2005).

Brazilian strategic interests revealed at the United Nations General Assembly

In analyzing statements by President Dilma at the UN General Assembly (UNGA), we can perceive concepts that guide the foreign policy of her government. Among the most frequent and emphatic ones are the following: multilateralism and democratization of multilateral institutions (perspective of the rise of multipolarity and of greater participation of developing countries); UN reform (global governance crisis and the need for reforms, especially in the UNSC); sustainable development(economic development associated to the eradication of poverty, with the zealous use of natural resources and with environmentally sustainable patterns of production and consumption); economic-financial equilibrium (criticism toward the financial market and the monetary, exchange and commercial policies of developed countries); protection of Human Rights (creation of the principle of Responsibility while Protecting and criticism of Human Rights violation through cybernetic espionage).

The issues regarding multilateralism and democratization of multilateral institutions are linked to the premise of a recent transformation in the international order. Dilma and her foreign policy makers seek Brazil's international integration in a world that has recently become multipolar but has retained obsolete mechanisms of debate and cooperation between nations. In this sense, the government defends multilateralism as the most reasonable way of maintaining world peace and stability in this new multipolar system (ROUSSEFF, 2011; 2014). Furthermore, it advocates greater democracy in multilateral forums, since, in this new context, the absence of developing (and especially emerging) countries in multilateral discussions compromises the global governance process' efficiency and restricts the legitimacy of these institutions (ROUSSEFF, 2011; 2012; 2013; 2015).

UN reform is linked to the previous concepts, also associated to the view of loss of efficiency and legitimacy of the bodies that maintain their structure and operations based on the outdated system. According to that perception, Dilma maintains that the world suffers not only from an economic crisis, but also from a political trust and governance crisis (ROUSSEFF, 2011). The countries who have the power to take action in international institutions no longer have the power to make their decisions legitimate and to compel other States to put their resolutions into practice. Thus, in the midst of the demands for reform of the UN Security Council, the president reiterates Brazil's interest and commitment to take part in the group of permanent members as a Latin American representative. Defending that 
Brazil is the greatest power in the region, Dilma's administration affirms that the country is likewise a reference in promoting peace, respect for $\mathrm{Hu}-$ man Rights and promotion of multilateralism (ROUSSEFF, 2012; 2014).

The development matter during Lula's administration focused on the so-called South-South cooperation, so that the developing countries would gain more space in the international system. Moreover, even though the concept of development allied to peace was present in his foreign policy agenda, the main emphasis was on the economic issue. To claim that the economic aspect was abandoned in the Dilma's government would be a misunderstanding. What occurred, in fact, was a greater attention to the promotion of elements that should accompany economic development, such as peace and security. From this conception, Brazil, under Dilma's foreign policy, proposed to aid developing countries in issues that go far beyond the financial aspect; reaching themes such as cooperation in food security, agricultural technology, clean and renewable energy generation and combat of poverty and hunger. In this sense, Brazil achieved a great victory with its performance of Rio+20 conference (ROUSSEFF, 2012).

At the conference, which was a mark of multilateralism, the country was able to approve the inclusion of points such as the fight against hunger and poverty as a Sustainable Development Goal. Thus, the search for domestic achievement and promotion of international efforts for a sustainable development model that combines economic growth, eradication of poverty, conscious use of natural resources and sustainable patterns of consumption and production was a milestone in the foreign policy of the Dilma government regarding development, cooperation and environmental care (ROUSSEFF, 2012; 2014; 2015).

The search for economic-financial equilibrium is based on criticisms of deregulation of the financial market, Currency War, protectionism of developed countries, and exclusion of emerging countries from the debate on solutions to the 2008 global economic crisis (ROUSSEFF, 2011; 2012). President Dilma's questioning, in general, concerns the use of orthodox policies by developed countries, which have negative effects on developing countries, forcing emerging countries to adopt criticized defense measures (ROUSSEFF, 2012). The president calls for a greater regulation of financial markets, in view of the need to control the indiscriminate entry of speculative capital that leaves the economy volatile. In addition, she recriminates the so-called-by the then Finance Minister, Guido Mantega -Currency War, a maneuver by developed countries that leaves Brazil at disadvantage in international trade. Nevertheless, she repudiates protectionism, vehemently denying accusations that Brazil uses such mechanism. Besides, in all her speeches the president was emphatic in her call for a decentralization of the world economic debate (ROUSSEFF, 2011; 2012; 2013).The demand for greater participation of developing countries in economic policy decisions was constant; as well as the demand for the deepening of interactions between the International Monetary Fund (IMF), the World Bank (WB), the WTO, the UN, and multilateral forums that are more representative, such as the G-20 -Dilma's main instrument regarding economic debates at the international level - (ROUSSEFF, 2012).

Continuing Brazilian diplomatic tradition of defending the protection of Human Rights, President Dilma condemned violence against civil- 
ians in insurgencies in the Middle East - in the context of the Arab uprisings. This led to debate on the principle of Responsibility while Protecting (RwP), a complement to the principle of Responsibility to Protect (R2P), which was questioned when humanitarian intervention in Libya became a military intervention for regime change (ROUSSEFF, 2011; 2012). The introduction of the Responsibility while Protecting principle was a daring move of the Dilma government's foreign policy, considered a concrete measure of demonstrating Brazil's ability to take diplomatic initiatives, underpinning Brazil's pursue for a permanent seat on the UNSC. Furthermore, the formulation of the principle marked a change of Brazilian position, which now admits the need for foreign intervention in certain circumstances. Another evidence of Brazil's tougher stance on Human Rights abuses under Dilma's government. Finally, another issue that was treated as a Human Rights violation by the president was the virtual espionage that assaulted the privacy of civilians, decision-makers and Brazilian strategic companies. It triggered efforts, especially in cooperation with Germany, to condemn such acts as a Human Rights violation (ROUSSEFF, 2013).

Turkish strategic interest revealed at the United Nations General Assembly.

When analyzing statements by Turkish representatives in the General Debates of the United Nations General Assembly between 2010 and 2015, one can identify concepts that have been guiding Turkish foreign policy in this period. Among the most frequent and emphatic ones, are the following: multilateralism and democratization of multilateral institutions (perspective of the rise of multipolarity, UN reform, strengthening of the G-20, commitment to international law, defense of nuclear non-proliferation); protection of Human Rights (combat of terrorism and Islamophobia, concern for refugees); responsible development (commitment to humanitarian aid and cooperation with Least Developed Countries- LDCs -, notion of collective environmental responsibilities); and regional security and stability (promotion of democracy in the Middle East, encouragement of cooperation and economic interdependence with neighbors).

Turkey recognizes that the international system is in the process of multipolarization and, therefore, believes that it is necessary to adapt multilateral institutions to this new order. In this way, Turkey advocates for a reform in the UN system, especially in the Security Council - but not in the format intended by Brazil - (DAVUTOĞLU, 2012; 2015; ERDOĞAN, 2011; 2014; GÜL, 2010; 2013).Turkey also criticizes the traditional international financial institutions (IMF, WB etc) and emphasizes the role of the G-20 in overcoming the 2008 international economic crisis, advocating a strengthening of more democratic arrangements for such economic debates (DAVUTOĞLU, 2015; GÜL, 2010). In addition to these traditional demands from emerging countries, Turkey also demands greater respect for international law, especially regarding equal treatment between States (GÜL, 2010). In this sense, it questions the double standards for issues such as nuclear non-proliferation. Double standards cases, according to the country, damage the credit of international institutions. Therefore, Turkey calls for a new approach to the issue of nuclear 
non-proliferation; in order to be fair, it must have a more democratic and universal approach (GÜL, 2010).

In the point of Human Rights, Turkey criticizes the selectivity in statements proclaiming the protection of these rights. Thus, its representatives condemn what is considered as negotiability of these rights (DAVUTOĞLU, 2012; ERDOĞAN, 2011). Turkey advocates that Human Rights need to be respected unconditionally and emphasizes two types of violations that affect the country: Islamophobia and terrorism (DAVUTOĞLU, 2012; GÜL, 2013). For Turkey, the lack of confidence and lack of a sense of justice in the UN is a strengthening factor of terrorism and, so, the country reaffirms the necessity for reforms in this institution. It defends the combat of terrorism to be indiscriminate, regardless of political, ideological or religious orientation, and believes that combating terrorism is the greatest challenge of these days. In relation to Islamophobia, Turkish representatives affirm that prejudice and hate speech cannot be confused with freedom of expression (DAVUTOĞLU, 2012; 2015). The issue of refugees is of utmost concern to Turkey, especially since the beginning of the Syrian Civil War. According to the Turkish government, the country sees the issue of refugees and migrants in a more comprehensive perspective than a mere State security issue. The Turks deal with the matter through the binomial development-humanitarian aid in order to seek long-term solutions to the problem (DAVUTOĞLU, 2015; ERDOĞAN, 2014).

Turkey desires to be a model for the States of its region and also wants to project itself as a regional power concerned with others States globally. For that reason, the Turkish foreign policy applies the concept of responsible development. In this sense, the country, taking advantage of its good economic moment, emphasizes its willingness to assist in the development of other countries, especially those known as Least Developed Countries and African countries (GÜL, 2010; 2013). Turkey emphasizes its collaboration with humanitarian aid and its proposal for cooperation based on the principle of mutual benefits. In this regard, the cooperation agency of Turkey (TIKA, in Turkish) stands out (ERDOĞAN, 2011; GÜL, 2010). Regarding the environment, the country states that it should be considered as a global indivisible public good. Hence, the international community must assume collective responsibilities toward its protection (GÜL, 2010).

The core regional matter of Turkey is the promotion of regional security and stability, so that the country can develop itself and assume the role of regional power. Turkey - differently from Brazil - does not mention a process of regional integration, but stresses the importance of its efforts for greater cooperation in the different regions to which it belongs (Middle East, Caucasus, Balkans, and Central Asia) (DAVUTOĞLU, 2015; GÜL, 2010). Turkey sought to disseminate its model of democracy in the Middle East, in order to create a favorable environment to the expansion of relations, especially economic, between the countries of the region. The Arab Spring was a timely event in that direction, allowing Turkey to project itself as a regional leader in rebuilding a democratic Middle East. Nevertheless, it is known that in the course of this process the instability of the region only worsened, damaging the Turkish doctrine of "Zero Problems with the Neighbors". Besides, throughout the speeches in the 
UN General Debate, in the regional perspective Turkey also claims for the recognition of the Palestinian State and for the resolution of the Cyprus issue (ERDOĞAN, 2011; GÜL, 2010, 2013). In both cases, the country demands respect for international law and uses this theme as an example of UN's fragility regarding conflict resolution, again pointing the lack of democracy and representativeness in the organization. The conjuncture situation in its region made the issues of the Syrian Civil War, the DAESH (Islamic State) and the Failed State of Libya being constants in the speeches (DAVUTOĞLU, 2012; ERDOĞAN, 2011; GÜL, 2013).

Brazil and Turkey Bilateral Relations

Relations between Brazil and Turkey have grown rapidly and become increasingly relevant to these countries in the last decade. Although there have been bilateral agreements for more than 150 years, only in recent years a strategic partnership has been achieved (LAZAROU, 2016). In this context, there were official visits, signing of agreements and establishment of covenants -which involved both government and private sector-signaling a change in the way these countries relate (BRAZIL, 2011c).

In 2003, an important agreement was signed on cooperation in defense-related matters in order to promote the exchange of personnel for practical training, participation in courses, seminars, and conferences (BRAZIL, 2003). The year of 2004 was a mark for bilateral relations due to the visit of Celso Amorim, the first Brazilian Foreign Minister to visit Turkey in an official mission (BRAZIL, 2006b, p. 227-228). In the same year, Brazilian Minister of Development, Industry and Foreign Trade, Luís Fernando Furlan, and Defense Minister, José Viegas, also visited Turkey. Brazil received Turkish National Economy Minister, Kemal Unakitan, in Brasilia for the $1^{\text {st }}$ Meeting of Economic, Commercial and Industrial Cooperation between Brazil and Turkey (BRAZIL, 2010c). The result of the missions was noticed in the immediate trade increase in the following year (BRAZIL, 2011f).

Between 18 and 21 January 2006, Brazil received Deputy Prime Minister and Foreign Minister of Turkey, Abdullah Gül, accompanied by a delegation of approximately 50 people. He participated in the creation of the Brazil-Turkey Business Council and also visited Embraer and Turkish Honorary Consulate. The arrival of Deputy Prime Minister served to show the soaring interest of the two countries in strengthening their political and trade relations (BRAZIL, 2006b). For this reason, a Joint High-Level Committee was set up to foster cooperation in the following areas: "political dialogue, economy and trade, science, technology, defense industry, finance, investment, tourism, culture, cooperation between diplomatic academies, and other areas of mutual interest" (BRAZIL, 2006a). This commission became responsible for the significant approximation in later years.

Due to the convergence in several matters, these countries have achieved a higher degree of cooperation in areas such as political consultations - through the High-Level Cooperation Commission - and energy cooperation - with the installation of Petrobras in Turkey. Petrobras and the Turkish Petroleum Corporation (TPAO) have identified potential cooperation themes in several sectors. So, they have started work- 
ing together on oil and gas exploration on the Black Sea coast (BRAZIL, 2011c). In May 2009, President Lula made the first official visit of a Brazilian Head of State to Turkey. In his speech, President Lula emphasized the rapprochement between the two countries, with the creation of the High-Level Cooperation Commission, the installation of Petrobras in the country and the growth of bilateral trade.

By becoming conflict mediators, countries without great military or economic capabilities have found a way to exert influence on important issues in the international arena. Only so Brazil would be able to participate in peace and security issues in the Middle East, as suggested by President Lula (GHITIS, 2009). In this context, the former president was the mediator of an agreement signed in Tehran between Iranian President, Mahmoud Ahmadinejad, and Turkish Prime Minister, Tayyip Erdogan, in May 2010. The agreement concerned the Iranian nuclear program, criticized and seen as a threat to regional security and the nuclear non-proliferation system by the United States (FONTEIJN; ASSL; INGRAM, 2010). This achievement was only made possible due to the participation of Brazil and Turkey in the negotiations, in view of the unsuccessful negotiations conducted by the International Atomic Energy Agency (IAEA) in the previous year (SILVA, 2010).

Like Brazil, Turkey defends the right to develop nuclear energy research for peaceful purposes, in accordance with Article IV of the Non-Proliferation Treaty (NPT) (BRAZIL, 2010b; SILVA, LEÃES, 2014). The involvement in the Iranian issue has allowed Brazil and Turkey to bring positive influences in a region where the influence of the United States and Europe is viewed with apprehension by many (FONTEIJN; ASSL; INGRAM, 2010). Despite this effort, the UN Security Council approved a fourth round of sanctions on Iran. Turkey and Brazil were the only countries that voted against it, while Lebanon abstained (JORNAL DE BRASÍLIA, 2010). According to President Lula, the Tehran Declaration was not intended to solve all problems, but aimed at re-establishing dialogue, building trust between countries and overcoming controversies (BRAZIL, 2010d).

After joint efforts on the Iranian issue, the Prime Minister of Turkey came to Brazil in May 2010. Recep Tayyip Erdogan was at the inauguration of the General Consulate of Turkey in São Paulo, visited Embraer, met with President Lula and participated in the Brazil-Turkey Business Forum. This was the first visit of a Turkish Prime Minister to Brazil (ANATOLIA NEWS AGENCY, 2010). During this visit an action plan for the strategic partnership was established between the two countries (BRAZIL, 2010a).

Through this action plan, the strategic partnership can be built based on nine points. The first one is political dialogue and cooperation in multilateral forums, where both commit themselves to establishing interactions, exchanging information on their respective regions, especially on issues of peace and security. Brazil and Turkey have agreed to focus efforts on defending the goals of disarmament and non-proliferation of weapons of mass destruction. They have also pledged to articulate positions in multilateral forums. Furthermore, on the one hand, Brazil was in favor of bringing Tur- 
key closer to MERCOSUR; on the other hand, Turkey manifested its interest in approaching BRICS and IBSA, in order to facilitate dialogue between these countries, as well as expressed its support to Brazil's rapprochement with the Organization of the Islamic Conference (OIC) (BRAZIL, 2010a).

Second, the countries have defined the cooperation in the area of trade and investment. By that, these countries started to encourage the formation of public and private joint ventures in Brazil and Turkey as well as in third countries. They have highlighted cooperation with Africa, cooperation in research and development, and cooperation in the aeronautical sector. Third, it was pointed the energy cooperation, related to the presence of Petrobras in Turkey. Then, cooperation in the areas of biodiversity, as well as in the issues of environment and sustainable development. The sixth point is cooperation in the defense area, where countries reaffirmed their commitment to the 2003 agreement on this subject. The exchange for visits and training became the most important aspect, as well as the efforts for identifying business opportunities in the defense industry. For this purpose, it was proposed the creation of a joint working group on defense. The last three points deal with prevention of organized crime and terrorism, joint work in the area of science and technology, and cultural and educational cooperation (BRAZIL, 2010a).

As the same time of the establishment of the strategic partnership, trade relations increased significantly due to closer ties between the two countries. Trade increased by approximately 330\% between 2002 and 2008, reaching US\$2,195,456,920 until November 2011 (BRAZIL, 2011f). Brazilian exports are heavily concentrated in iron and iron ore, which accounted for approximately $30 \%$ of total volume of Brazil's exports to Turkey in 2011. But Brazil also exports soy, wheat, cotton, coffee, and tobacco to Turkey (BRAZIL, 2011d). Yet, Brazil imports a much more diversified list of intermediate goods such as iron and steel bars and wires, automobile bodywork accessories, artificial fiber yarns, and some types of motor vehicles (BRAZIL, 2011e).

The expansion of business is favored by the complementarity between the two economies. However, despite geographical distance, the greatest obstacle to trade relations is the so called cultural distance between the two countries: "insufficient institutional dialogue, limited integration of professional and business networks, restrictions to the transit and residence of professionals, and different patterns of consumption" (BRAZIL, 2009, p. 63). As these two economies expand and reach more fields globally, it becomes more urgent to overcome these differences.

The visit of President Dilma Rousseff in October 2011 served to reaffirm the interest of the two countries in narrowing ties, finding new affinities, and strengthening the strategic partnership. The countries signed acts in higher education, agreements on the transfer of convicted persons and juridical assistance in criminal matters (BRAZIL, 2011a). Proofs of the continuation of the close relations between the two countries in Dilma's government were Brazilian support for Turkey's candidacy for a non-permanent seat in the UN Security Council for the 2015-2016 mandate and, at the same time, Turkish appeal to Brazil's entry as an observer at the Organization of Islamic Cooperation (BRAZIL, 2011c). 
However, the first major divergence faced by the countries was the situation in countries affected by the wave of riots during the Arab Spring. In general, Brazil and Turkey dealt differently with these events (BRAZIL, 2011b). Notwithstanding, the advisory body of the Brazilian presidency affirmed that different perceptions regarding the situation of the Arab world in the post Arab Spring period do not mean divergences per se, only different ways of dealing with the matter.

Therefore, despite the promising strategic partnership, changes in the international scenario and in the domestic environment have hindered the intensity of bilateral relations in recent years. The Arab Spring profoundly reoriented relations in the Middle East, provoking a relative withdrawal from Brazil and deepening Turkey's engagement in its region. In the meantime, both countries have faced, especially since 2013, a complex and fragile domestic political conjuncture, with growing popular manifestations and institutional instability, culminating in the soft coup d'état in Brazil - through the impeachment process of President Dilma Rousseff -and in the attempt of military coup in Turkey, both in 2016.

Final Remarks

The analysis of the official statements of Brazil and Turkey in the last decade, in a comparative perspective, allows us to recognize the points of agreement and disagreement in the interests agenda of each country, as well as to identify the themes that are of more relevance for one country or the other. The independent variable is the fact that the countries are emerging and considered medium powers by the literature. The dependent variables were the positions regarding subjects present in their international agenda. The comparison of the discourses allows us to conclude that the two countries converge in some general subjects, but that their histories, national interests, and projection in different regions give them different positions in several topics of their respective agendas. Overall, Turkey's positioning is rhetorically stronger than Brazil's, with firmer and more assertive positions, except for the issue of Human Rights, in which Turkey tends to have a more defensive position than Brazil.

Regarding the Arab Spring, Brazil and Turkey naturally dealt differently with the events. Brazil, of which some analysts expected more assertive positions by virtue of the more emphatic defense of Human Rights under Dilma Rousseff's administration, followed its tradition of caution regarding regime change, condemning violations of rights, but opposing external interference in domestic matters. Hence, the country did not take sides with governments and possible regime changes, guaranteeing the possibility of establishing good relations with the States involved, whatever the outcome of the riots.

Turkey has gone through several contradictions that have put an end to the policy of good relations with its neighbors (the so called "Zero Problems with the Neighbors" policy). By prioritizing the promotion of its democratic model, Turkey counted on heavy riots that would gen- 
erate rapid changes in regimes, allowing the country to maintain good relations with the new governments of that time. This is what happened with Tunisia and Egypt. Meanwhile, the situation in Libya and, above all, in Syria, bound Turkey to the discourse of necessity of regime change, causing a rupture in diplomatic relations with the governments in power, and involving Ankara in its neighbors' civil wars. In this way, a Turkish lapse in the projection of scenarios has led to the dismantling of the successful regional policy of the last decade. As a result, while Turkey suffered with negative consequences both politically and economically, Brazil was able to remain politically well-disposed in the region undergoing only economic losses.

Table 1 - Synthetic frame: strategic interests in comparative perspective

\begin{tabular}{|c|c|c|}
\hline & BRAZIL & TURKEY \\
\hline a) Economic development model & $\begin{array}{l}\text { The government presents two main axes in its development model: } \\
\text { poverty reduction and technological development. Presence of the } \\
\text { State as an inducer of the economy. }\end{array}$ & $\begin{array}{l}\text { Turkey focuses its economic growth on attracting foreign investments, } \\
\text { which fosters its industrialization and promotes its exports. The State } \\
\text { is present as the main regulator, and controls some important sectors, } \\
\text { although the private sector is strong. }\end{array}$ \\
\hline b) Relations with the USA & $\begin{array}{l}\text { Strategic Dialogue - Commercial Difficulties. Differences of vision in } \\
\text { various themes, such as the Doha Round, humanitarian intervention, } \\
\text { nuclear issue and the Middle East. }\end{array}$ & $\begin{array}{l}\text { The US was Turkey's main ally during the Cold War, despite some } \\
\text { occasional deviations. Since 2003, there have been some frictions, but } \\
\text { countries still have close ties. }\end{array}$ \\
\hline c) Defense of multipolarity & $\begin{array}{l}\text { Imminence of a multipolar world. Brazil seeks to insert itself in this } \\
\text { new order with two purposes: on the one hand, to promote commu- } \\
\text { nication between the already consolidated poles; on the other hand, } \\
\text { to ensure that the poorest and minor States are actually represented, } \\
\text { building an inclusive multilateralism. }\end{array}$ & $\begin{array}{l}\text { After decades conditioning its foreign policy based on alignment with } \\
\text { the United States, Turkey gained a more assertive view from } 2002 \\
\text { on, advocating multipolarity and its role as a regional leader. There is } \\
\text { an emphasis on Turkish capacity to assist in conflict resolution and in } \\
\text { development promotion through international cooperation. }\end{array}$ \\
\hline $\begin{array}{l}\text { d) United Nations Security Council } \\
\text { (UNSC)'s reform }\end{array}$ & $\begin{array}{l}\text { It advocates a reform of the Security Council, with the greater pres- } \\
\text { ence of developing countries. Participates in the G-4 (Brazil, Japan, } \\
\text { India, and Germany). }\end{array}$ & $\begin{array}{l}\text { Criticizes the Security Council for failing to represent nations } \\
\text { equitably. Veto power is also questioned. Crisis of Syria illustrates the } \\
\text { inability of the UNSC to deal with international conflicts. Contrary to } \\
\text { the G4 proposal. }\end{array}$ \\
\hline e) Climate change and development & $\begin{array}{l}\text { Defends the principle of "common but differentiated responsibilities". } \\
\text { Signatory of the environmental protocols. }\end{array}$ & $\begin{array}{l}\text { Is signatory to the Protocols of Montreal and Kyoto but does not } \\
\text { usually highlight the environment issue in its official statements. }\end{array}$ \\
\hline f) Terrorism and Humans Rights & $\begin{array}{l}\text { Brazil participates in the UN Human Rights Council. It argues that } \\
\text { there are violations in every country, without exception, and char- } \\
\text { acterizes authoritarianism, xenophobia, misery, capital punishment, } \\
\text { and discrimination as forms of Human Rights violation. It criticizes } \\
\text { indifference to terrorism, but also advocates "responsibility while } \\
\text { protecting". }\end{array}$ & $\begin{array}{l}\text { Terrorism is central to Turkish foreign policy because of the conflict } \\
\text { with the Kurdish separatist group, the PKK. In addition, terrorism is } \\
\text { seen as a destabilizing element, which is particularly serious in the } \\
\text { Middle East, a region that Turkey prioritizes in international relations. } \\
\text { Combating terrorism is one way of promoting stability and the Turkish } \\
\text { role in the region. The country is admonished for its Human Rights } \\
\text { violations, mainly against the minorities as the Kurds, but the Turkish } \\
\text { government has been careful to defend itself against criticism. }\end{array}$ \\
\hline g) Nuclear research development & $\begin{array}{l}\text { Brazil has abdicated nuclear weapons, allowing the use of nuclear } \\
\text { energy only for peaceful purposes. It advocates disarmament and } \\
\text { non-proliferation, but it supports the right of nuclear production for } \\
\text { peaceful purposes. }\end{array}$ & $\begin{array}{l}\text { Turkey has no pretension of obtaining an atomic bomb but considers } \\
\text { sacred the right to nuclear technology for peaceful purposes. The } \\
\text { country is developing its nuclear capability and has worked with Brazil } \\
\text { to resolve the Iranian nuclear issue. }\end{array}$ \\
\hline $\begin{array}{l}\text { h) World Trade Organization (WTO) - trade } \\
\text { liberalization and the Doha Round }\end{array}$ & Defends the positions of the commercial G-20, created in 2003. & $\begin{array}{l}\text { Little action in the Doha Round. Turkish economy is essentially for the } \\
\text { export of manufactured goods, made in industries that have European } \\
\text { or North American FDI. At this point, the country remains with a } \\
\text { positioning close to the richest States. }\end{array}$ \\
\hline i) Global economic governance (G-20) & $\begin{array}{l}\text { In order to overcome the economic crisis, it is necessary to coordinate } \\
\text { the efforts of the countries within the multilateral organizations, such } \\
\text { as the G-20, the IMF and the World Bank. To contain the recession, } \\
\text { these agencies must foster a reformulation of the relationship } \\
\text { between fiscal and monetary policy, as well as control over the } \\
\text { currency war. }\end{array}$ & $\begin{array}{l}\text { There is a need for changes in global economic governance, in order to } \\
\text { enable the development of the poorest nations. Turkey also condemns } \\
\text { the excessive liberalization of the financial sector, responsible for the } \\
\text { latest economic crisis. However, the close ties with the US and the EU } \\
\text { make Ankara's positioning not so clear on the issue. }\end{array}$ \\
\hline j) South-South cooperation & $\begin{array}{l}\text { Strengthening South-South cooperation in the last decade (especially } \\
\text { with Africa and Latin America). Brazil became aware of its interna- } \\
\text { tional responsibilities. Thus, the government is expanding its technical } \\
\text { cooperation program with less developed countries, focusing on } \\
\text { agriculture and food security, education, vocational training, justice, } \\
\text { sport, health, environment, information technology, labor, urban } \\
\text { development, and bioenergy. }\end{array}$ & $\begin{array}{l}\text { There has been a great incentive to South-South cooperation since } \\
\text { 2002, with the rise of AKP. It highlights the possibilities for Turkey } \\
\text { to play a regional leadership role, resolving conflicts and promoting } \\
\text { social economic development. In addition, Ankara also seeks to get } \\
\text { closer to other developing or emerging countries, such as Brazil, China } \\
\text { and Russia, showing that there are common interests, especially with } \\
\text { regard to defending multipolarity in international relations. }\end{array}$ \\
\hline k) Regional integration & $\begin{array}{l}\text { Mercosur and South America remain a priority to Brazilian foreign pol- } \\
\text { icy. Avoiding harassment of major powers, ensuring regional security } \\
\text { and deepening the integration process. }\end{array}$ & $\begin{array}{l}\text { The Middle East is the priority of Turkish foreign policy, and its foreign } \\
\text { policy formulators see a prominent role for the country in the region. } \\
\text { However, the existence of many conflicts undermines the possibility of } \\
\text { an eventual regional integration. }\end{array}$ \\
\hline
\end{tabular}

Source: Prepared by the authors, based on BRAZIL (2003,2010a, 2011a, 2011b, 2011c),

DAVUTOĞLU(2011, 2015), GÜL (2010, 2013), ERDOĞAN (2011, 2014); KANAT (2014);

AKMAN (2012), BABACAN (2011) 
References

AKMAN, Sait.Turkey in the World Trading System and the WTO: Activism under Global Challenges and the EU Process. Afro Eurasian Studies, v. 1, n. 1, p. 134-172, 2012.

ALTUNISIK, Meliha; TÜR, Özlem. Turkey: Challenges of continuity and change. London: Routledge, 2005.

AMORIM, Celso. Conceitos e estratégias da diplomacia do governo Lula. DEP - Diplomacia, Estratégia e Política, v. 1, n. 1, p. 41-48, 2004.

ANATOLIA NEWS AGENCY Turkish PM Erdoğan arrives in Brazil. Hurryet Daily News, 2010. Available at: http://archive.hurriyetdailynews.com/n.php?n=turkish-pm-erdogan-arrives-in-brazil-2010-05-26. Accessed on: 26 aug. 2020.

BABACAN, Mehmet. Whither an axis shift: A perspective from Turkey's foreign trade. Insight Turkey, v. 13, n. 1, p. 129-157, 2011.

BRAZIL. Ministério das Relações Exteriores. Acordo sobre a cooperação em assuntos relacionados a defesa entre o Governo da República Federativa do Brasil e o Governo da República da Turquia. 2003. Available at: http://dai-mre.serpro.gov.br/atos-internacionais/ bilaterais/2003/b_46. Accessed on: 26 aug. 2020.

BRAZIL. Ministério das Relações Exteriores. Action Plan for Strategic Partnership between the Federative Republic of Brazil and the Republic of Turkey. 2010a. Available at: http://daimre.serpro.gov.br/atos-internacionais/bilaterais/2010/action-plan-for-strategic-partnership-between-the-federative-republic-of-brazil-and-the-republic-of-turkey. Accessed on: 26 aug. 2020.

BRAZIL. Ministério das Relações Exteriores. Atos assinados por ocasião da visita da Presidenta da República, Dilma Rousseff, à Turquia. 2011a. Available at: http://www.itamaraty. gov.br/sala-de-imprensa/notas-a-imprensa/atos-assinados-por-ocasiao-da-visita-da-presidenta-da-republica-dilma-rousseff-a-turquia-ancara-e-istambul-6-a-8-de-outubro-de-2011/?searchterm=turquia\%20visita\%20de\%20dilma. Accessed on: 26 aug. 2020.

BRAZIL. Ministério das Relações Exteriores. Brasil e Turquia divergem. 2011b. Available at: http://www.itamaraty.gov.br/sala-de-imprensa/selecao-diaria-de-noticias/midias-nacionais/ brasil/jornal-de-brasilia/2011/10/09/brasil-e-turquia-divergem/?searchterm=turquia. Accessed on: 26 aug. 2020.

BRAZIL. Ministério das Relações Exteriores. Declaração Conjunta - Brasil-Turquia: Uma Perspectiva Estratégica para uma Parceria Dinâmica. 2011c. Available at: http://www.itamaraty.gov.br/sala-de-imprensa/notas-a-imprensa/brasil-turquia-uma-perspectiva-estrategica-para-uma-parceria-dinamica/?searchterm=turquia\%20visita $\% 20 \mathrm{de} \% 20 \mathrm{dilma}$. Accessed on: 26 aug. 2020.

BRAZIL. Ministério do Desenvolvimento, Indústria e Comércio Exterior. Exportação Brasileira-Turquia: Principais Produtos. 2011d. Available at: http://www.mdic.gov.br//sitio/interna/ interna.php?area $=5 \&$ menu=2477\&refr=576. Accessed on: 26 aug. 2020 .

BRAZIL. Ministério do Desenvolvimento, Indústria e Comércio Exterior. Importação Brasileira-Turquia: Principais Produtos. 2011e. Available at: http://www.mdic.gov.br//sitio/interna/ interna.php?area $=5 \&$ menu $=2477 \&$ refr $=576$. Accessed on: 26 aug. 2020 .

BRAZIL. Ministério do Desenvolvimento, Indústria e Comércio Exterior. Intercâmbio Comercial Brasileiro-Turquia. 2011f. Available at: http://www.mdic.gov.br//sitio/interna/interna. php?area $=5 \&$ menu=2477\&refr $=576$. Accessed on: 26 aug. 2020 .

BRAZIL. Ministério das Relações Exteriores. Memorando de Entendimento entre o Governo da República Federativa do Brasil e o Governo da República da Turquia para a Criação de Comissão Conjunta de Alto Nível. 2006a. Available at: http://dai-mre.serpro.gov.br/atos-internacionais/bilaterais/2006/b_3. Accessed on: 26 aug. 2020.

BRAZIL. Ministério do Desenvolvimento, Indústria e Comércio Exterior. Oportunidades de negócios em serviços Brasil-Turquia. Brasília. 2009.

BRAZIL. Resenha de Política Exterior do Brasil. Brasília: Ministério das Relações Exteriores, 2010b.

BRAZIL. Turquia: Temas Políticas e Relações Bilaterais. Brasília: Ministério das Relações Exteriores, 2010c.

BRAZIL. Resenha de Política Exterior do Brasil. Brasília: Ministério das Relações Exteriores, 2006b. 
BRAZIL. Resenha de Política Exterior do Brasil. Brasília: Ministério das Relações Exteriores. 2010d.

CERVO, Amado; BUENO, Clodoaldo. História da Política Exterior do Brasil. Brasília: Editora UnB, 2011.

DAVUTOĞLU, Ahmet. Address by H.E. Mr. Ahmet Davutoğlu, Minister of Foreign Affairs of the Republic of Turkey, to the General Debate of the 67th Session of the UN General Assembly. New York: UN General Assembly, 2012.

DAVUTOĞLU, Ahmet. Address by H.E. Mr. Ahmet Davutoğlu, Prime Minister of the Republic of Turkey, to the General Debate of the 70th Session of the UN General Assembly. New York: UN General Assembly, 2015.

ERDOĞAN, Recep Tayyip. Address by H.E. Mr. Recep Tayyip Erdoğan, Prime Minister of the Republic of Turkey, to the General Debate of the 66th Session of the UN General Assembly. New York: UN General Assembly, 2011.

ERDOĞAN, Recep Tayyip. Address by H.E. Mr. Recep Tayyip Erdoğan, Prime Minister of the Republic of Turkey, to the General Debate of the 69th Session of the UN General Assembly. New York: UN General Assembly, 2014.

FONTEIJN, Maarten, ASSL, Nima; INGRAM, Paul. New players in the Dispute over Iran's Nuclear Program. British American Security Information Council (BASIC), 2010.

GHITIS, Frida. Mediation as the Third Path to Global Power. World Politics Review, dez. 2009.

GÜL, Abdullah. Address byH.E. Abdullah Gül, President of the Republic of Turkey, to the General Debate of the 65th Session of the UN General Assembly. New York: UN General Assembly, 2010

GÜL, Abdullah. Address byH.E Abdullah Gül, President of the Republic of Turkey, to the General Debate of the 68th Session of the UN General Assembly. New York: UN General Assembly, 2013.

GÜN, Mustafa. The USA-Turkey relationship after 2003 Iraq crisis. Bilge Strategi, v. 2, n. 2, p. 137-168, 2009 .

HIRO, Dilip. Inside Central Asia. New York: The Overlook Press, 2009.

HUDSON, Valerie; VORE, Christopher S.. Foreign policy analysis: yesterday, today and tomorrow. Mershon International Studies Review, v. 2, n. 2, p. 209-238, 1995.

JORNAL DE BRASÍLIA. Conselho de Segurança da ONU aprova sanções contra o Irã; Brasil e Turquia votam contra. Jornal de Brasília, 2010. Available at: http://www.jornaldebrasilia.com. br/site/noticia.php?id=284755. Accessed on: 26 aug. 2016.

KANAT, Kiliç Bugra. Theorizing the Transformation of Turkish Foreign Policy. In: KANAT, Kiliç Bugra; TEKELIOGLU, Ahmet Selim; ÜSTÜN, Kadir (ed.). Change and Adaption in Turkish Foreign Policy. Ankara: Seta, 2014, p. 19-44.

LAZAROU, Elena. Brazil-Turkey Relations in the 2000s: Deconstructing Partnership between Emerging Powers. Insight Turkey, v. 18, n. 1, p. 123-141, 2016.

LIJPHART, Arend. Comparative Politics and the Comparative Method. The American Political Science Review, v. 65, n. 3, p. 682-693, 1971.

LIMA, Maria Regina Soares de. A política externa brasileira e os desafios da cooperação Sul-Sul. Revista Brasileira de Política Internacional, v. 48, n. 1, p. 24-59, 2005.

NOLTE, Detlef. How to compare regional powers: analytical concepts and research topics. Review of International Studies, v. 36, n. 4, p. 881-901, 2010.

OLIVEIRA, Marcelo Fernandes de. Alianças e coalizões internacionais do governo Lula: o Ibas e o G-20. Revista brasileira de política internacional, v. 48, n. 2, p. 55-69, 2005.

PECEQUILO, Cristina Soreanu. A política externa do Brasil no século XXI: os eixos combinados de cooperação horizontal e vertical. Revista Brasileira de Política Internacional, v. 51, n. 2, p. 136-156, 2008

ROSENAU, James N. Comparative Foreign Police: Fad, Fantasy or Field?. International Studies Quaterly, v. 12, n. 3, p. 296-329, 1968.

ROUSSEFF, Dilma. Discurso da Presidenta da República, Dilma Rousseff, por ocasião do Debate Geral da 66 $^{\mathbf{a}}$ Assembleia Geral das Nações Unidas. New York: UN General Assembly, 2011.

ROUSSEFF, Dilma. Discurso da Presidenta da República, Dilma Rousseff, por ocasião do Debate Geral da 67 $^{\text {a }}$ Assembleia Geral das Nações Unidas. New York: UN General Assembly, 2012. 
ROUSSEFF, Dilma. Discurso da Presidenta da República, Dilma Rousseff, por ocasião do Debate Geral da 68 $^{\text {a }}$ Assembleia Geral das Nações Unidas. New York: UN General Assembly, 2013.

ROUSSEFF, Dilma. Discurso proferido pela Presidenta da República, Dilma Rousseff, por ocasião da abertura do Debate de Alto Nível da 69ª Assembleia Geral das Nações Unidas (ONU). New York: UN General Assembly, 2014.

ROUSSEFF, Dilma. Discurso da Presidenta da República, Dilma Rousseff, por ocasião da Abertura da 70 ${ }^{\mathbf{a}}$ Assembleia Geral das Nações Unidas. New York: UN General Assembly, 2015.

SILVA, André Luiz Reis da. As relações do Brasil com o Irã e a Turquia e a questão nuclear. Meridiano 47 - Boletim de Análise de Conjuntura em Relações Internacionais, v. 11, n. 118, p. 3-5, 2010.

SILVA, André Luiz Reis da. Geometria variável e parcerias estratégicas: a diplomacia multidimensional do governo Lula (2003-2010). Contexto Internacional, v. 37, n. 1, p. 143-184, 2015.

SILVA, André Luiz Reis da; LEÃES, Ricardo. A Convergência Turco-Brasileira na Declaração de Teerã (2010). Mural Internacional, v. 5, n. 2, p. 148-162, 2014.

VIGEVANI, Tullo; CEPALUNI, Gabriel. A política externa de Lula da Silva: a estratégia da autonomia pela diversificação. Contexto Internacional, v. 29, n. 2, p. 273-335, 2007.

WILSON, Dominic; STUPNYTSKA, Anna. The N-11: More than an acronym. Economics Paper, New York: Goldman Sachs Global, 2007.

YILMAZ, Bahri. The relations of Turkey with EU: Candidate forever?. Working Paper Series, Center for European Studies, 2008. 